\title{
Neuroptera of the Amazon Basin. Part 1. Sisyridae
}

\author{
Norman D. Penny (")
}

\begin{abstract}
Known species of the Neuropteran family Sisyridae of the Amazon Basin are described, figured, and distributions are given for this region. Two new species of Sisyra and one of Climacia are described, bringing the total number of species known from Amazonia to eight. Keys are presented for Amazonian species of Sisyra and Climacia.
\end{abstract}

\section{INTRODUCTION}

The Neuropteran family Sisyridae is among the smallest in the order, with only 45 species known from five extant genera. The family is widely distributed throughout most tropical and warm temperate areas of the world. Within the Amazon Basin exist two genera of Sisyridae: Climacia with three species (only one of which was previously known from Amazonia), and Sisyra with five species, two of which are new and herein described.

The family is unique among the Planipennia in having aquatic larvae which are parasitic on fresh-water sponges of the genera Meyenia and Spongilla. Lestage (1921) has stated that larvae are also parasites of filamentous algae and bryozoans.

\section{BIOLOGY}

Small, pale yellow eggs are laid in small crevices directly above water. They are covered by several strands of whitish silk. Eggs hatch within 8 days to two weeks, whereupon the large-headed, first instar larva drops into the water and seeks out a sponge host. Sisyridae go through three larval instars. The third instar, when ready to pupate, will leave the water and wander up to 16 meters from the water and finally spin a silken cocoon on almost any roughened surface. Oftentimes, a fine network of silken strands will form an outer structure within which the cocoon is spun. In warm temperate zones, two to three generations occur per year, but in the Amazon Basin emergence is almost continuous, with the peak coming in July and August in the central Amazon. Adults may feed on pollen grains and nectar (Brown, 1952) and are attracted to lights, often in large numbers.

\section{SYSTEMATICS}

In the most recent revision of the Sisyridae, Parfin and Gurney (1956) recognized one species of Climacia and one species of Sisyra as existing in the Amazon Basin. During the present study, one additional known species of Climacia and two of Sisyra were found to occur within the Basin. Finally, two formerly unknown species of Sisyra and one new species of Climacia were also collected.

The following morphological descriptions use the terminology for male genitalia of Parfin and Gurney (1956) .

\section{KEY TO AMAZONIAN GENERA OF SISYRIDAE}

1A. A series of outer gradate crossveins present in fore and hind wings ........ ............... Climacia MacLachlan

1B. No series of outer gradate crossveins present in either wing .............. Sisyra Burmeister

\section{Genus Climacia MacLachlan, 1869}

Climacia MacLachlan. 1869, Ent. Monthly Mag., 6:21.

Type Species: Micromus areolaris Hagen, by original designation of MacLachlan.

(") - Instituto Nacional de Pesquisas da Amazônıa, Mlanaus. 


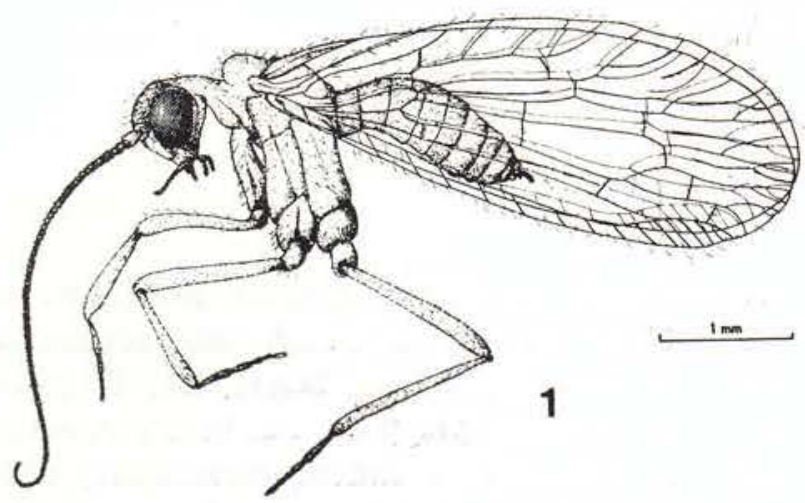

Figure 1 - Lateral view of Sisyra amazonica, n. sp. (reprinted from Penny and Arias, 1981).

Head: Rounded with somewhat elongated mouthparts. Compound eyes entire, without pilosity. Ocelli absent. Maxillary palpi threesegmented. Last segment elongate and apically pointed. Labial palpi three-segmented. Antennae filiform, of 46 to 63 segments.

Thorax: Pronotum quadrate with numerous long setae. Meso- and meta- nota convex, pilose. Meso- and metapleura elongate, with few setae. Legs elongate, consisting of globular coxa, quadrangular trochanter, elongate femur and tibia. Two tibial spurs present. Five tarsal segments, first as long as proximal three. Two tarsal claws present.

Wings: Forewings with a basic pale coloration. A series of outer gradate crossveins present. Two or three R-Rs crossveins present. Terminal segment of most longitudinal veins branched.

Abdomen: Ten very lightly sclerotized segments. Male genitalia consisting of a series of dentitions along caudal margin of tenth sternum, setiferous ninth sternum, and membranous aedeagus. Female genitalia consisting of elongate, sclerotized ninth tergum and sternum, and lightly sclerotized tenth tergum.

\section{KEY TO AMAZONIAN SPECIES OF CLIMACIA}

1A. A conspicuous radiomedial streak in forewing $\ldots \ldots \ldots \ldots \ldots \ldots \ldots 2$

1B. No conspicuous radiomedial streak in forewing .......... C. townesi P.\&G.
2A. Forewing with basal radiomedial streak not accompanied by extensive spotting along longitudinal veins $\ldots \ldots \ldots \ldots \ldots$. .............. C. bimaculata Bks.

$2 \mathrm{~B}$. Forewing with basal radiomedial streaks accompanied by extensive spotting along longitudinal veins .... C. negrense n.sp.

\section{Climacia bimaculata Banks, 1913}

Climacia bimaculata Banks, 1913, Proc. Ent. Soc. Wash., $15: 138$.

Holotype female (in glycerin) in Museum of Comparative Zoology, Harvard University, Cambridge, Massachusetts, U.S.A.

Present description based on 3 males, 5 females, 1 ? on slides and 1 male, 1 female pinned.

Head: Yellow with somewhat elongate mouthparts. Maxillary palps bright yeilow, threesegmented, elongate. Last palpal segment apically acute. Labial palpi also three-segmented, yellow, and terminal paipal segment acutely pointed. Antennae 46 to 48 segmented, with basal and apical whorls of dark setae on each segment. First eight antennal segments yellow, next 15 segments dark fuscous, gradually returning to a pale yellow apicaily. Compound €yes large, black. Ocelli absent.

Thorax: Yellow, numerous setae stramineous. Legs yellowish, except for tip of last tarsal segment dark fuscous.

Wings: In forewing (Fig. 2) costal field with 14 to 15 crossveins before pterostigmal area, where crossveins become very numerous. R, uniting with $\mathrm{Sc}$ beneath pterostigmal area. Three crossveins between $R_{1}$ and $R s$; one in radiomedial band, one at end of pterostigmal spot, and and one midway between pterostigmal crossvein and wing margin. Three other outer gradate crossveins approximately below pteorstigmal spot. A series of four crossveins midway between radiomedial stripe and pterostigmal spot forming an inner gradate series. Three additional crossveins in field of radiomedial streak forming basal gradate series. Forewing bright yellow, except for radiomedial 
streak, pterostigmal spot, and most crossveins fuscous. Occasional longitudinal streaking in cells beyond outer gradate series of crossveins.

Hindwing pale yellow with more sclerotization in area of pterostigma, extending to wing apex. Diffuse fuscous pterostigmal spot. Outer gradate series of three crossveins. Inner gradate series of four crossveins. Anal area with long, curved setae.

Abdomen of Male: First nine abdominal segments very lightly sclerotized. Tenth sternum with caudal ring of long setae with dentiferous bases. This structure projects ventro-caudally as a concave lobe with many strong setae (Fig. 10). Ninth sternum a raised ridge evenly curving to a medial, ventral projection.

Body Length: Male, $3.0-3.5 \mathrm{~mm}$; female, $4.0-4.2 \mathrm{~mm}$.

Forewing Length: Male, 3.6 - $4.0 \mathrm{~mm}$; female, $3.6-4.1 \mathrm{~mm}$.

Variation: One male and one female lack the dark longitudinal streaks near the wing apex, and this same male has antennae which are uniformly dark. This may be a brood difference, as this male was the only one caught during the early part of the year.

Geographical Distribution: Holotype female of this species was collected at Bartica, Guyana. Parfin \& Gurney (1956) record an additional female from Zanderiu I, Boven Para District, Surinam. Additional material in the Systematic Entomology Collections of INPA, Manaus include BRAZIL: Amazonas, km $244-$ AM 010, 19-I-1977, N.D. Penny, 1 male; Amazonas, Manaus, 7-IX-1978, N.D. Penny, I female; Amazonas, km 246 - AM 010, 12-16-VII-1979, Jorge R. Arias, 3 males, 4 females, 1 ?. All were collected with light traps.

Temporal Distribution: The female type was collected in December and the Surinam specimen in April. One Amazonas specimen was collected in January, another in September, and a series of eight specimens in July. It appears that this species may be present at all times of the year.
Ecology: The specimen collected in January was taken from a small black-water stream running through an extensive white sand area. The Manaus specimen was taken from an apartment in the city center near the Igarapé de São Raimundo, a heavily polluted inlet of the Rio Negro. The other Amazonas specimens were collected from a light trap placed in the top of a large tree about $1 / 2 \mathrm{~km}$ from the Rio Urubu where it crosses AM 010. It would appear that this species can be taken near both small streams and large rivers.

Climacia bimaculata appears to be most closely related to the other two Amazonian species, $C$. negrense and $C$. townesi, and the Paraguayian species, C. carpenteri, although the distinct two marks on the wings easily distınguishes $C$. bimàculata.

\section{Climacia negrense n.sp.}

Holotype male, on a slide, in the Systematic Entomology Collections of INPA, Manaus . Description based on holotype male.

Head: Yellow with fuscous markings on occiput and frons. Antennae consisting of 46 segments (only first 28 remaining on right antenna); first eight segments stramineous, becoming dark fuscous on proximal 12 segments, and apical segments gradualiy returning to stramineous. Maxillary and labial palpi stramineous.

Thorax: Notal region setiferous, stramineous with fuscate markings. Pleural regions fuscous. Coxa and trochanter fuscous, remainder of leg stramineous. Pilosity of legs stramineous.

Wings: Forewing (Fig. 3) stramineous with extensive fuscous markings. Radiomedial streak diagonal from Sc to medial vein. Pterostigmal spot large, triangular, reaching to $R_{2}+3$. All crossveins fuscous and fuscous spotting along longitudinal veins. CuP and anal veins stramineous, bordered by linear fuscous streaks. Further fuscous streaking in cells of forewing apex. Hindwing with reduced pigmentation and number of crossveins. 
Abdomen of Male: Abdominal segments very lightly sclerotized. Tenth sternum bearing caudal ring of long setae with dentate bases. A setiferous medial projection extending caudally directly below the dentate ring, and a lateral projection directly below this. A concave ventral depression on ventral surface of genitalia (Fig. 11).

Female Unknown.

Body Length: Male, $2.5 \mathrm{~mm}$.

Forewing Length: Male, $4.3 \mathrm{~mm}$.

Geographical Distribution: The holotype and only known specimen was collected at BRAZIL: Amazonas, Barcelos, Norman D. Penny, I male.

Temporal Distribution: The holotype was taken on 15-I-1978.

Ecology: The holotype was taken from a black (ultraviolet) light trap operating atop a boat moored on the Rio Negro at Barcelos.

Climacia negrense appears similar to $C$. bimaculata, C. carpenteri, and C. townesi. C. negrense can easily be separated from $C$. bimaculata and $C$. townesi by the much more extensive fuscous markings in the anal area of the forewing. The male terminalia appear similar to $C$. townesi, but caudal projections are more acute and the concave depression is present in C. negrense.

This new species is named after the Rio Negro, from its type locality.

\section{Climacia townesi Parfin \& Gurney, 1956}

Climacia townesi Parfin \& Gurney, 1956, Proc. U.S. Natn. Mus., $105: 509$.

Holotype female (in alcohol) in Museum of Comparative Zoology, Harvard University, Cambridge, Massachusetts, U.S.A.

Present description based on 50 males, 70 females, 1 ? pinned; and 4 males, 3 females, 1 ? on slides.

Head: Fuscous with somewhat elongate mouthparts. Maxillary palpi bright yellow, three-segmented, elongate. Last palpal segment apically acute. Labial palpi three-segmented, yellow, apically acute. Antennae 47 to 63 segmented, with basal and apical whorls of dark setae on each segment. First 27 segments fuscous, gradually shading to pale yellow apically. Compound eyes large, black. Ocelli absent.

Thorax: Yellow with slight, diffuse fuscous markings. Legs yellowish, except for tip of last tarsal segment dark fuscous.

Wings: In forewing costal field with 14 to 15 crossveins before pterostigmal area, where crossveins become very numerous. $R_{1}$ uniting with Sc beneath pterostigmal area. Two crossveins between $R_{1}$ and $R s$; one just before pterostigma, and one directly below pterostigma. Series of five irregular crossveins forming inner gradate series. Forewing pale yellow, except for two short, fuscous bands in anal area and darkened crossveins (Fig. 4). Hindwing pale yellow throughout. Outer gradate series of six crossveins, and one crossvein forming remnant of inner gradate series.

Abdomen of Male: First nine abdominal segments very lightly sclerotized. Tenth sternum with caudal ring of long setae poorly developed. Lateral lobe of tenth sternum very heavily sclerotized, with long setae with dentiferous bases. Ninth sternum forming a medial, ventral, setiferous projection (Fig. 12) .

Body Length: Male, $3.0-3.4 \mathrm{~mm}$; female, $3.0-4.5 \mathrm{~mm}$.

Forewing Length: Male, $3.5-3.7 \mathrm{~mm}$; female, $3.5-4.0 \mathrm{~mm}$.

Variation: Little variation is demonstrated from the present specimens, although males appear to have about 10 antennal segments more than females.

Geographical Distribution: The holotype was collected on the "Corry River, Brazil" by H.S. Parrish. No Corry River exists on present day Brazilian maps. However, one day earlier the same collector collected other specimens of this same species at Tapajos (Rio Tapajós) on a trip down the Amazon River. Therefore, the locality has to be somewhere near Santarém at the mouth of the Rio Tapajós, although it was listed as "Rio Coari" in Parfin \& Gurney (1956). Other specimens in the U.S. National Museum and Museum of Comparative Zoology are from PERU: Iquitos, H.S. Parrish, 2?; Napo River, H.S. Parrish, 5?; BRAZIL: "Santa Fe- 
lipe", H.S. Parrish. "Santa Felipe" does not exist on current Brazilian maps and there are two localities labelled "São Felipe" in Roraima Territory, quite some distance north of the Amazon River. Additional material in the Systematic Entomology Collections of INPA, Manaus include: BRAZIL: Amazonas, Manaus, Norman D. Penny, 50 males, 70 females, 1?; Amazonas, km 246 - AM 010, Jorge R. Arias. 4 males, 3 females, 1 ?.

Temporal Distribution: The Peruvian specimens were collected from 8 May to 16 June, while the Brazilian specimens have been collected from 24 June to 26 August.

Ecology: This species appears to be the most common sisyrid in central Amazonia. They have been found on several of the major tributaries of the Amazon River and in mid-July adults can be collected in large numbers with light traps near large rivers.

This species of Climacia can be immediately separated from all other Climacia, except C. bimaculata, by the fuscous anal area of the forewing. C. townesi lacks the pterostigmal spot of C. bimaculata.

\section{Genus Sisyra Burmeister, 1839}

Sisyra Burmeister, 1839, Handbuch der Entomologie,

$$
2: 975 \text {. }
$$

Type Species: Hemerobius fuscatus Fabricius, designated by Banks, 1905:25.

Head: Rounded with mouthparts not elongated. Compound eyes entire, without pilosity. Ocelli absent. Maxillary palpi five-segmented; penultimate segment short; ultimate segment basally expanded, but tapering to acute point. Labial palpi three-segmented; last segment triangular, expanded. Antennae filiform, of 31-38 segments.

Thorax: Pronotum quadrate with numerous long setae. Meso- and metanota convex, sparsely pilose. Meso- and metapleura elongate, few setae. Legs elongate, consisting of globular coxa, short trochanter, elongate femur and tibia. Two small tibial spurs present. Five tarsal segments, first as long as proximal three. Two tarsal claws present.
Wings: Forewings with a basic dark coloration (Fig. 5). Outer gradate veins absent. Two R-Rs crossveins present. Terminal segment of most longitudinal veins branched.

Abdomen: Ten very lightly sclerotized segments. Male genitalia with tenth tergum and ninth sternum reduced to small, setiferous sclerites. Laterally tenth sternum expanded, heavily sclerotized. Female genitalia of small, setiferous tenth tergum, larger quadrate ninth tergum and elongate, unsegmented ninth sternum.

\section{KEY TO AMAZONIAN SPECIES OF SISYRA}

1A. No longitudinal veins of forewing with light streaks; antennae yellowish with basal two segments fuscous; all femora fuscous; male tenth sternum beak-like, sharply curved dorso-ventrally to point ................. S. minuta E.-P.

1B. Ail iongitudinal veins of forewing broadly bordered with light streaks; antennae variable; at least fore femur pale yellow ...................... 2

2A. Male tenth sternum more than four times as long as wide; antennae yellowish basally $\ldots \ldots \ldots \ldots \ldots \ldots \ldots, 4$

2B. Male tenth sternum only about twice as long as wide; antennae dark throughout ................... 3

3A. Male tenth sternum stout, thick and mitten-like .......... S. ariasi n.sp.

3B. Male tenth sternum quadrangular, without ventral thumb-like lobe .......... S. panama P.\&G.

4A. Male tenth sternum without basal, ventral projection; antennae yellowish with basal two segments somewhat darker ....... ............... S. amazonica n.sp.

4B. Male tenth sternum with basal, ventral projection; antennae with first two segments yellowish, proximal 12 segments fuscous, and terminal segments yellowish ........... S. apicalis Bks. 


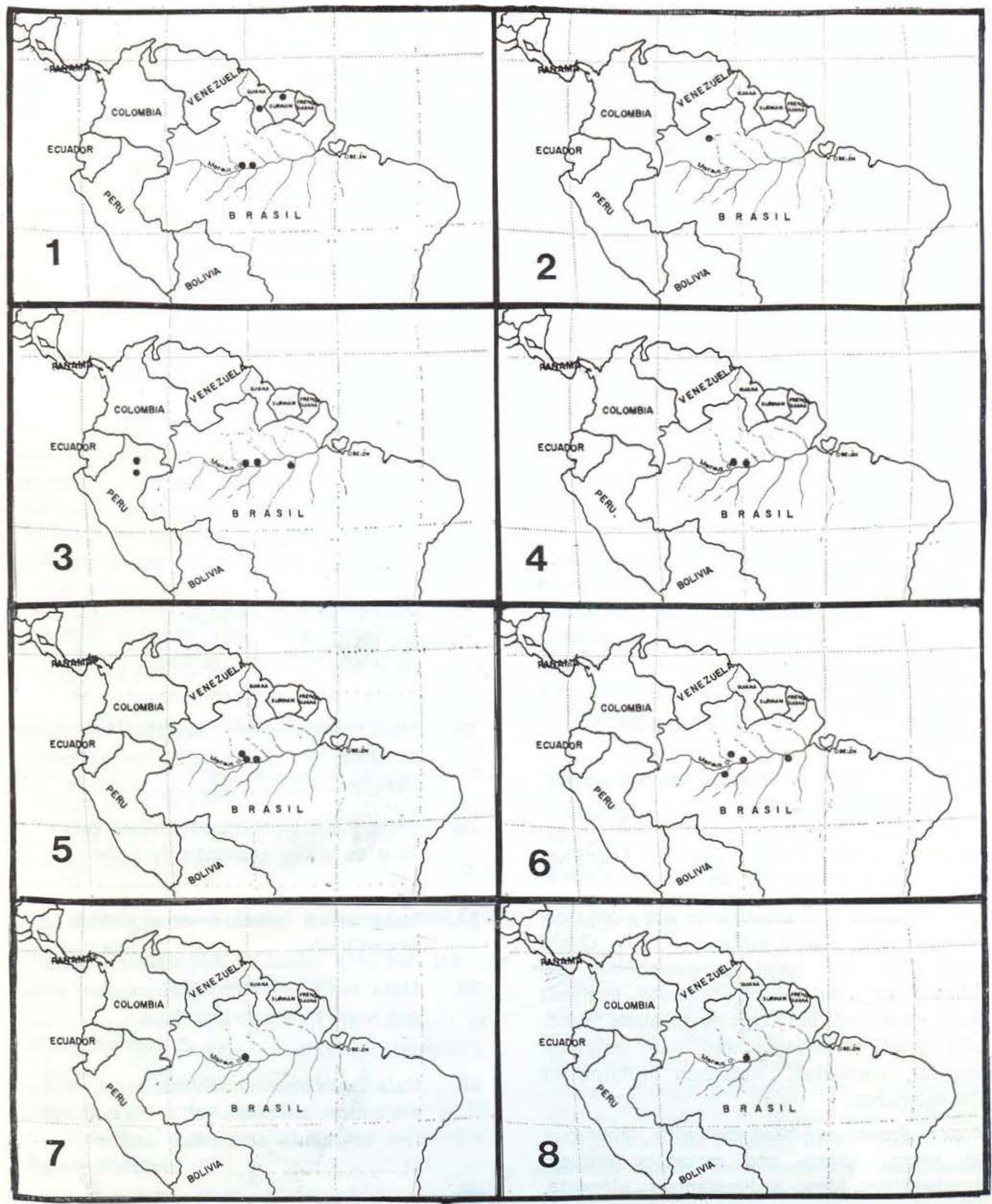

Maps. 1-8-Geographical distribution of 1) Climacia bimaculata Banks, 2) Climacia negrense, n. sp., 3) Climacia townesi Parfin \& Gurney, 4) Sisyra amazonica, n. sp., 5) Sisyra apicalis Banks (in South America), 6) Sisyra minuta E. P., 7) Sisyra panama P. \& G., 8) Sisyra ariasi, n. sp. 
Sisyra amazonica n.sp.

Holotype male on slide in the Systematic Entomology Collections of INPA, Manaus.

Present description based on type series of 3 males and 7 females on slides; 1 male, pinned.

Head: Yellowish, with extensive infuscation. Maxillary palpi fuscous, five-segmented, short, except last segment very broad basally, tapering to point apically. Labial palpi short, three-segmented, dark fuscous, and last segment broadly triangular. Antennae with basal segment fuscous; subsequent segments pale yellow; of at least 25 segments. Compound eyes large, black. Ocelli absent.

Thorax: Fuscous, numerous setae pale yellowish. Foreleg yeliowish. Midfemur dark fuscous. Terminal midleg segments yellowish. Hindfemur yellowish or fuscous. Terminal hindleg segments yellowish.

Wings: In forewing, costal field with 12 crossveins before pterostigmal area (Fig. 5) . Two crossveins between $R_{1}$ and $R s$; three crossveins forming inner gradate series and four others forming irregular basal gradate series. Forewing pale yellow basaliy and fuscous apically with longitudinal veins apically bordered with pale yellow. Hindwing uniformly light fuscous; with three crossveins.

Abdomen of Male: First nine abdominal segments very lightly sclerotized. Tenth tergum and ninth sternum also lightly sclerotized and without projections. Tenth sternum elongate, only gradually tapering; without dorsal or ventral basal projections (Fig. 13) ,

Body Length: Male, $1.5-2.8 \mathrm{~mm}$; female, $2.5-3.0 \mathrm{~mm}$.

Forewing Length: Male, 3.0-3.2 mm; female, 3. $0-3.2 \mathrm{~mm}$.

Variation: Coloration of the hindfemur can vary from yellow to fuscous. Antennae in all specimens appear broken, so that variation in antennal segmentation is not possible to assess with the present series.

Geographical Distribution: This species has only been collected twice. The collection records are: BRAZIL: Amazonas, Reserva
Ducke, km 26 - AM 010, Norman and Ana Penny, 2 females; Amazonas, km 246 - AM 010, Jorge R. Arias, 3 males, 5 females.

Temporal Distribution: This species has only been coilected on 30 June and 12-16 July in central Amazonia.

Ecology: The Reserva Ducke collection site was a light trap at least $1 / 2$ kilometer from any running water, and 6 or 7 kilometers from any large streams. The $\mathrm{km} 246$ - AM 010 locality was a light trap set in the top of a tree only $1 / 2$ kilometer from the large Rio Urubu.

This species is part of the "apicalis" group having only two radial crossveins. It can be separated from $S$. minuta by the light streaking of the wings and elongate male tenth sternum. S. amazonica can be separated from S. panama and $S$. ariasi by the pale yellow antennae. The most closely related species, S. apicalis, has distinctively patterned antennae and projections of the male tenth sternum.

This species is named for the river system from which it comes. Holotype male, allotype female and 1 female paratype are deposited in the Systematic Entomology Collections of INPA, Manaus. Further paratypes have been distributed to the following collections: Museu Nacional do Rio de Janeiro, Brazil; Museu de Zoologia, Universidade de São Paulo, Brazil; Museu Paraense Emílio Goeldi, Belém, Pará, Brazil; British Museum, Natural History, London, England; U.S. National Museum, Washington. D. C., U. S. A.; Museum of Comparative Zoology, Harvard University, Cambridge, Massachusetts, U.S.A.; Commonwealth Scientific and Industrial Research Organization, Canberra. Australia.

Sisyra apicalis Banks, 1908

Sisyra apicalis Banks, 1908, Trans. Amer. Ent. Soc., $32: 261$.

Holotype female, pinned, in the Museum of Comparative Zoology, Harvard University, Cam. bridge, Massachusetts, U.S.A.

Present description based on 3 males, 5 females pinned; and 31 males, 18 females on slides. 
Head: Yellowish. Maxillary palpi five-segmented. Palpal segments yellowish, short; except last segment fuscous, enlarged basally, tapered apically. Labial palpi short, three-segmentea, light fuscous, and last segment widely triangular. Antennae with basal two segments pale yellow, becoming fuscous for proximal 13 segments; then abruptly changing to pale yellow; terminal two to four segments again fuscous; total of 34 segments. Compound eyes large, black. Ocelli absent.

Thorax: Fuscous, numerous setae yellowish, Foreleg yellowish throughout. Mid and hind coxae, trochanter and basal part of femur dark fuscous. Mid and hind tarsi, tibia, and apical part of mid and hind femur yellowish.

Wings: In forewing, costal field with 11 crossveins before pterostigmal area (Fig 6) . Two crossveins between $R_{1}$ and $R s$; three crossveins forming inner gradate series and four others forming irregular basal gradate series. Forewing fuscous with longitudinal veins basally bordered by pale yellow, becoming obscured apically. Hindwing uniformly light fuscous; with three crossveins.

Abdomen of Male: First eight abdominal segments very lightly sclerotized. Tenth tergum aind ninth sternum also lightly sclerotized and without projections. Tenth sternum elongate, nearly parallel-sided; with small, acute, basomedial projections on the lower and upper surface (Fig. 14) .

Body Length: Male, $2.1-2.8 \mathrm{~mm}$; female, $2.7-3.0 \mathrm{~mm}$.

Forewing Length: Male, $3.2-3.8 \mathrm{~mm}$; female, $3.3-3.7 \mathrm{~mm}$.

Variation: The specimen I have before me from Florida lacks the small, acute projection at the dorsal base of the claspers, which is present in all Amazonian specimens. This difference may represent a distinct species, but as the species is so distinctive, and no other differences are apparent, I prefer to maintain the Amazonian specimens within the known species. Such variation would not be surprising in such a wide-ranging species.
Geographical Distribution: Parfin \& Gurney (1956) record this species from the southeastern U.S.A., CUBA, and PANAMA. Additional specimens in the Systematic Entomology Collections of INPA, Manaus include: BRAZIL: Amazonas, Reserva Ducke, km 26 - AM 010, 3-X-1978, Jorge R. Arias, 1 female; Amazonas, Reserva Ducke, km 26 - AM 010, 30-VI-1979. Norman and Ana Penny, 1 male, 1 female; Amazonas, Reserva Ducke, km 26 - AM 010, 10-VII-1979, Jorge R. Arias, 1 female; Amazonas, Manaus, 28-VII-1978, Norman D. Penny, 1 male; Amazonas, km 152 - BR 319, 31-I-1979, Eloy Castellon, 1 male; Amazonas, km $275-$ BR 319, 6-IV-1978, Norman D. Penny, 1 female; Amazonas, km 246 - AM 010, 12-16-VII-1979, Jorge R. Arias, 31 males, 19 females.

Temporal Distribution: This species can be collected at any time of the year, but appears to be most common during June and July in central Amazonia.

Ecology: This species is frequently collected in light traps far away from large bodies of water. This has raised doubts as to whether larvae actually feed on freshwater sponges, as do most sisyrids. An alternative explanation is strong powers of dispersal among abundant adults.

Sisyra apicalis is part of the "apicalis" group having two radial crossveins and longitudinally streaked wings. This species can easily be separated from other members of the group by the strikingly patterned antennae and projections of the male tenth sternum.

Sisyra minuta Esben-Petersen, 1935

Sisyra minuta Esben-Petersen, 1935, Konowia, 14:152.

Holotype male, pinned, in the Naturhistorisches Museum, Vienna, Austria.

Present description based on holotype, 1 male 7 females pinned; 4 males on siides.

Head: Fuscous. Maxillary palpi fuscous, fivesegmented, short, except last segment very broad basally, tapering to point apically. Labial 
palpi short, three-segmented, dark fuscous, and last segment broadly triangular. Antennae with basai two segments fuscous; subsequent 31 segments pale yellow. Compound eyes large, black. Ocelli absent.

Thorax: Fuscous; pilosity fuscous. Legs pale fuscous, with femur often darker than subsequent leg segments.

Wings: In forewing, costal field with 10 crossveins before pterostigmal area (Fig. 7). Two crossveins between $R_{1}$ and $R s$; three crossveins forming inner gradate series and three others forming basa! gradate series. Forewing fuscous throughout. Hindwing pale fuscous with three crossveins. Central crossveins pale colored.

Abdomen of Male: First eight abdominal segments lightly sclerotized. Tenth tergum and ninth sternum also lightly sclerotized and without projections. Tenth sternum short, beaklike, sharply curved dorso-ventrally to point (Fig. 15) .

Body Length: Male, $1.6-3.0 \mathrm{~mm}$; female, $2.0-3.0 \mathrm{~mm}$.

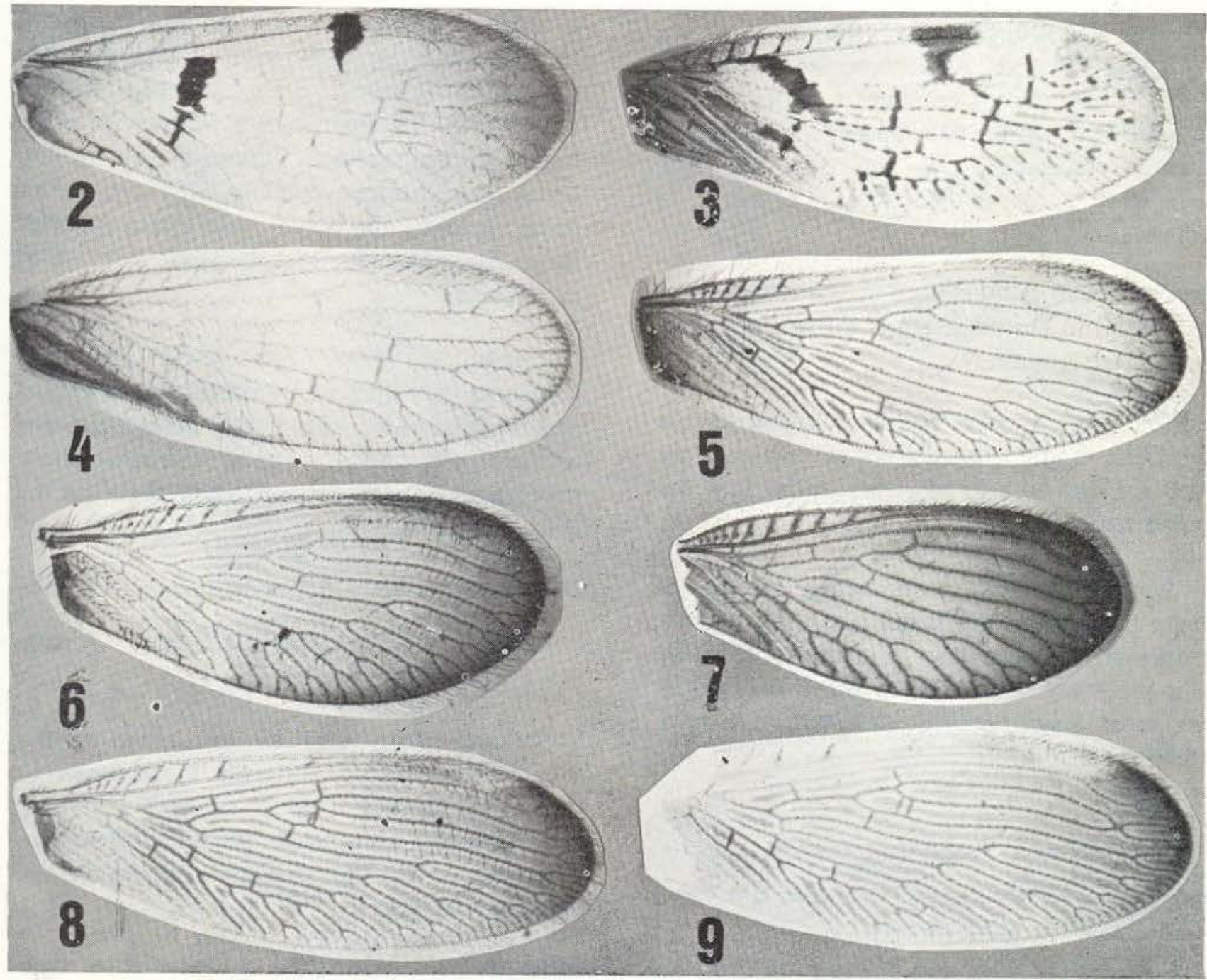

$+$

Figs. 2-9-Right forewing of 2) Climacia bimaculata Banks, 3) Climecia negrense, n. sp., 4) Climacia townesi, P. \& G., 5) Sisyra amazonica, n. sp., 6) Sisyra apicalis Banks, 7) Sisyra minuta E.-P., 8) Sisyra panama P. \& G.. 9) Sisyra ariasi, n. sp. 
Forewing Length: Male, $2.9-3.0 \mathrm{~mm}$; female, $3.3-3.7 \mathrm{~mm}$.

Variation: Most variation is in degree of pigmentation of the legs, whicn shade from pale yellowish to pale fuscous to dark fuscous.

Geographical Distribution: The holotype male is from Taperinha, near Santarém in Pará State, BRAZIL. Additional specimens in ths Systematic Entomology Collections of INPA, Manaus include: BRAZIL: Amazonas, Reserva Campinas, km 45 - BR 174, 1-X-1976, Norman D. Penny, 1 female; Amazonas, Reserva Campinas, km 45 - BR 174, 3-III-1977, Norman D. Penny, 1 female; Amazonas, Reserva Ducke, km 26 - AM 010, 19-IX-1977, Norman D. Penny, 1 male, 3 females; Amazonas, km 152 - BR 319, 31-l-1979, Eloy Castellon, 1 male; Amazonas, Manaus, 21-III-1979, Arias and Young, 1 female; Amazonas, km 246 - AM 010, 12-16-VII-1979, Jorge R. Arias, 3 males, 1 female.

Temporal Distribution: This species appears to be present in the adult stage all year round in the central Amazon.

Ecology: This species has been found almost anywhere in the central Amazon where light traps are set-near large rivers or far into the upland forest.

Sisyra minuta is a distinctiva species of Sisyra because of the small size, lack of pale streaks on the forewings and stout, beak-like male tenth sternum. Of the other Amazonian species of Sisyra, only S. amazonica has pale antennae.

Sisyra panama Parfin and Gurney, 1956

Sisyra panama Parfin \& Gurney. 1956, Proc. U. S. Natn. Mus., $105: 474$.

Holotype female and allotype male, pinned, in the U.S. National Museum, Washington, D.C.. U.S.A.

Present description based on 1 male, 1 female pinned, and 1 male on slide.
Head: Dark yellow to fuscous. Maxillary palpi yellowish, five-segmented, short, except last segment very broad basally, tapering to point apically. Labial palpi short, three-segmented, yellowish, and last segment broadly triangular. Antennae completely fuscous, of 38 segments. Compound eyes large, black. Ocelli absent.

Thorax: Fuscous, numerous setae pale yellowish. Foreleg yellowish. Mid femur dark fuscous. Terminal midleg segments yellowish. Hindleg segments yellowish.

Wings: In forewing, costal field with seven crossveins before pterostigmal area. Two crossveins between $R_{1}$ and Rs; five crossveins forming inner gradate series, including two distinctive proximal ones between $R_{3}$ and R4 +5 (Fig. 8). Four others forming irregular basa: gradate series. Forewing pale yellow basally and fuscous apically with longitudinal veins apically bordered with pale yellow. Hindwing uniformly iight fuscous; with three crossveins.

Abdomen of Male: First eight abdominal segments very lightly sclerotized. Tenth tergum and ninth sternum also lightly scierotized and without projections. Tenth sternum short, quadrangular, with several small teeth at the apex (Fig. 16) .

Body Length: Male, $3.0 \mathrm{~mm}$; female, $3.2 \mathrm{~mm}$. Forewing Length: Male, $3.7 \mathrm{~mm}$; female $4.0 \mathrm{~mm}$.

Variation: Little variation was noted in the present specimens, although illustrations in Parfin and Gurney (1956) suggest a slightly less truncate male tenth sternum. However, this may be due to the angle at which the drawing was made.

Geographical Distribution: The original type series consisted of a female holotype and male allotype from PANAMA: Gatún Lake, Caño Saddle, 8-V-1923, R.C. Shannon, 1 female; Coclé Prov., Farallón, 8-XI-1952, F.S. Blanton, 1 male. Additional records in the Systematic 


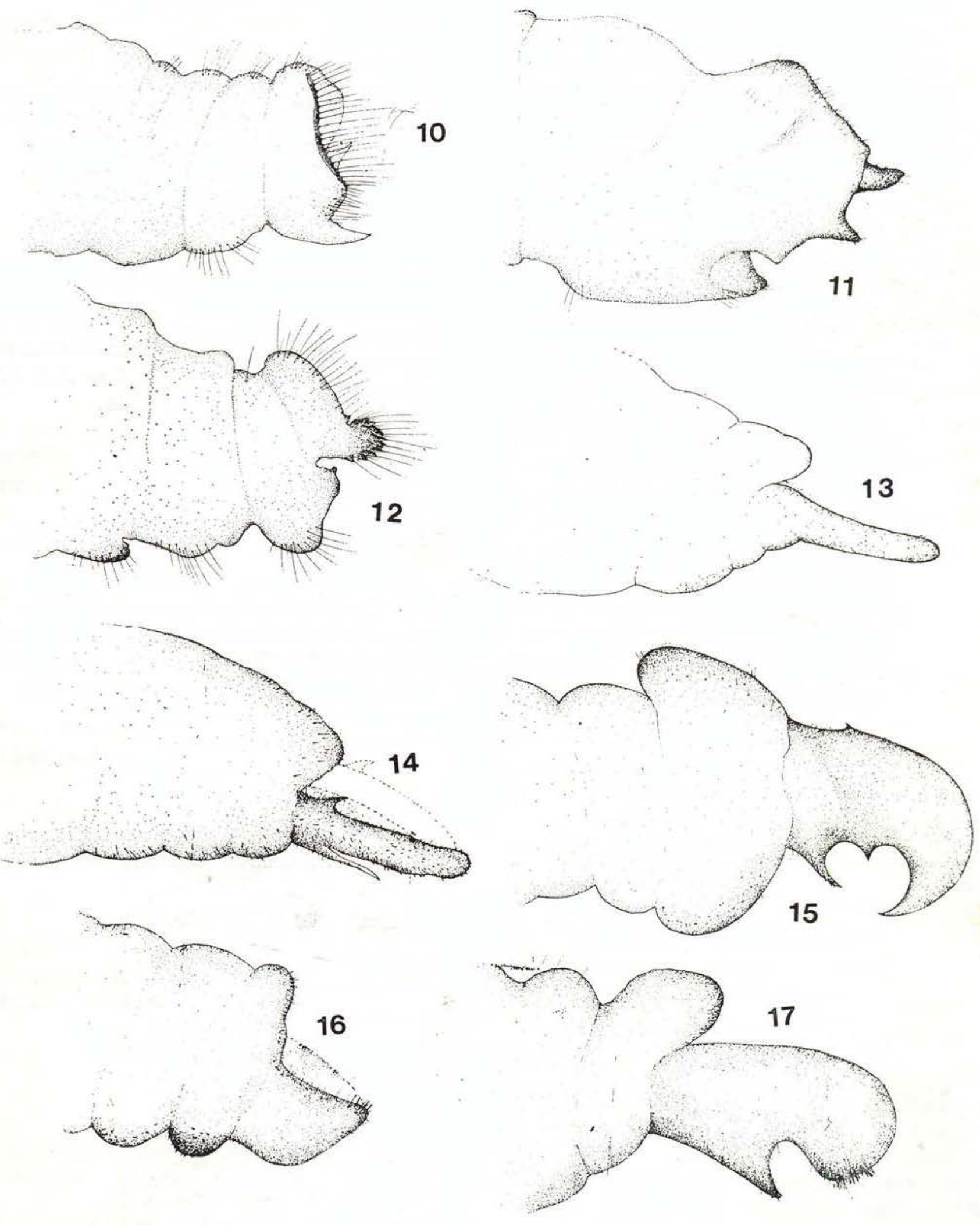

Figs. 10-17 - Lateral view of male genitalia of 10) Climacia bimaculata Banks, 11) Climacia negrense, $\mathrm{n}$. sp., 12) Climacia townesi P. \& G., 13) Sisyra amazonica, n. sp., 14) Sisyra apicalis Banks, 15) Sisyra minuta E..P. 16) Sisy ra panama P. \& G., 17) Sisyra ariasi, n. sp. (drawings by Alberto Coelho da Silva). 
Entomology Collections of INPA, Manaus include: BRAZIL: Amazonas, Manaus 28-VII e 9-VIII-1978, Norman D. Penny, 2 males, 1 female.

Temporal Distribution: Records from Panama indicate a May and November emergence while Amazonian records are for July and August.

Ecology: This species has only been caught near large rivers with light traps in central Amazonia. It is not a common species in that part of the range.

Sisyra panama is a member of the "apicalis" group with streaked wings and two radial crossveins, but the completely dark antennae and stout, truncate male tenth sternum are distinctive for this species. S. ariasi shares the dark antennae and stout male tenth sternum, but in $S$. ariasi the form of the tenth sternum is different.

\section{Sisyra ariasi n.sp.}

Original description based on 1 male, slide mounted.

Holotype male in the Systemtaic Entomology Collections of INPA, Manaus.

Head: Dark yellow. Maxillary palpi yellowish, five-segmented, short, except last segment very broad basally, tapering to point apically. Labial palpi short, three-segmented, yellowish, and last segment broadly triangular. Antennae completely fuscous, of 38 segments. Compound eyes large, black. Ocelli absent.

Thorax: Fuscous, numerous setae pale yellowish. Foreleg yellowish. Midfemur dark fuscous. Terminal midleg segments yellowish. Hindleg segments yellowish.

Wings: In forewing, costal field with seven crossveins before pterostigmal area. Two crossveins between $R_{1}$ and Rs; five crossveins forming inner gradate series, including two distinctive proximal ones between $R_{3}$ and $R_{4}+5$. Four other crossveins forming irregular basai gradate series. Forewing pale yellow basally and fuscous apically with longitudinal veins apically bordered with pale yellow (Fig. 9). Hindwing uniformly light fuscous; with three crossveins.
Abdomen of Male: First eight abdominal segments very lightly sclerotized. Tenth tergum and ninth sternum also lightly sclerotized and without projections. Tenth sternum short, mitten-shaped, with basoventral, acute projection (Fig. 17).

Body Length: Male, $3.0 \mathrm{~mm}$.

Forewing Length: Male, $3.7 \mathrm{~mm}$.

Geographical Distribution: The original type series consists of one male specimen collected at BRAZIL. Amazonas, $\mathrm{km} 246$ - AM 010 , 12-VII-1979, Jorge R. Arias, 1 male.

Ecology: This holotype male was collected from a large light trap set in the top of a tree $(40 \mathrm{~m})$ about $1 / 2 \mathrm{~km}$ from the fairly large Rio Urubu.

Sisyra ariasi can be separated from other species of Sisyra by the darkened antennae, light streaking of the forewing, and stout male tenth sternum. Sisyra panama is most closely related, having the above characteristics and the peculiar double crossvein between $R_{3}$ and $\mathrm{R} 4+5$, but has rhomboidal rather than mittenshaped male tenth sternum.

\section{ACKNOWLEDGMENTS}

I would like to thank Dr. Jorge R. Arias for much of the collected material for this study, Barbara Gibbs for the wing photographs, and Alberto Coelho da Silva for the genital drawings and maps.

\section{RESUMO}

As espécies conhecidas de Neuroptera Sisyridae, da Bacia Amazônica, são redescritas e figuradas, acompanhadas da distribuição de cada uma na região. Ainda são descritas três espécies novas para a ciência, duas do gênero Sisyra e uma de Climacia, elevando o número total das espécies conhecidas de Sisyridae da Amazônia, para oito. Também são apresentadas chaves para identificação das espécies Amazônicas dos dois gêneros. 


\section{REFERENCES}

BANKS, N

1905 - A revision of the Nearctic Hemerobiidae. Trans. Amer. Ent. Soc., $32: 21-51$, pls. 3-5.

1908 - Neuropteroid insects notes and descriptions. Trans. Amer. Ent. Soc., 34 : 255-267, pls. 17-19.

1913 - New exotic neuropteroid insects. Proc. Ent. Soc. Wash., $15: 137-143$.

BROWN, H.P.

1952 - The life history of Climacia areolaris (Hagen), a neuropterous "parasite" of fresh water sponges. Amer. Midland Nat., 47: 130-160, 16 figs.

Burmeister, H.C.C.

1839 - Handbuch der Entomologie, 2:757-1050. Berlin.

ESBEN-PETERSEN, P.

1935 - Two new species of Neuroptera. Konowia, $14: 151-153,2$ figs.
Lestage, J.A.

1921 - Sous-Famille II. - Sisyrinae. In Rousseau, E., Les Larves et Nymphes Aquatiques des Insetes d'Europe, 1:337-342, figs. 101-103.

MacLachlan, R.

1869 - New species... of Hemerobiina; with synonymic notes (first series). Ent. Monthly Mag., $6: 21-27$.

PARFin, S.I. \& GURNEY, A.B.

1956 - The spongilla-flies, with special reference to those of the Western Hemisphere (Sisyridae, Neuroptera). Proc. U.S. Nat. Mus., $105: 421-529,24$ figs., 3 pls.

PENNy, N.D. \& ARIAS, J.R.

1981 - Insects of an Amazon Forest. Columbia University Press, New York.

(Aceito para publicação em $11 / 03 / 80$ ) 